\title{
幾何学的非線形を考慮した曲げ一せん断部材の座屈後挙動 \\ 一免震構造用積層ゴム支承の座屈安定性問題への適用一 \\ THE EFFECT OF GEOMETRICAL NONLINEARITY ON THE BUCKLING LOAD OF SHEAR-BENDING COLUMNS
}

\author{
西村 功* \\ Isao NISHIMURA
}

This paper evaluates the effect of geometrical nonlinearity on the buckling load of shear-bending columns. The motivation of this study comes from the recognition that the linear buckling model proposed by Haringx in 1948 seems well fit to the experimental observation in the author's laboratory where high-rise rubber bearings were tested. It, however, contradicts to the numerous test results in the past research both in domestic and overseas as well. As a result of the study in this paper, the geometrical nonlinearity is shown to have a malevolent effect on the post-buckling behavior latent in the low-rise laminated rubber bearings, which are commonly used in a practical design of base-isolated buildings.

Keywords: buckling load, base isolation, Haringx model, geometrical nonlinearity, elliptic function 座屈荷重、免震構造、ハリンクスモデル、幾何学的非線形、楕円関数

\section{1 序論}

本論文は、免震構造の主要部材である積層ゴム支承の座屈モデル について考察したものである。

著者は、兔震構造に用いられる積層ゴム支承の座屈安定性を向上 させる目的で、中空孔を有する積層ゴム支承の鉛直剛性、曲げ剛性、 などについて実験と解析の両面から検討を加えてきた ${ }^{(1)(2)(3)(4) 。 そ の ~}$ 結果、積層鋼板に比較的厚みのある材料を用いると Haringx モデル で予想される座屈荷重がほぼ正確に実験で再現されることや、大き な変形を生じた後も、荷重一変形関係が高い線形性を示すことなど の実験結果を得た ${ }^{(4)}$ 。

一方、円形断面積層ゴム支承の座屈荷重は Haringx モデル(5)(6)(7) で予測されると考えられているが、実際に実験を行うと実験結果は 理論值を下回る場合が多く、Haringx モデルの妥当性には疑問が残る。 そのため、幾何学的な非線形性が座屈荷重の低下を引き起こす主た る原因であると見なされ、P- $\delta$ 効果を加味して理論値を修正するこ とが行われてきた ${ }^{(8)(9)}$ 。

では、両者の違いはどうして生じたのであろうか。勿論、こうし た違いが中空断面積層ゴム支承に特有の現象であるのか、それとも 積層ゴム支承の力学モデルを一般的に再考する必要があるのかは、 一概には断定できない。しかしながら、免震構造の主要部材である 積層ゴム支承ついて、座屈安定性という基本的部材特性を考察する モデルに疑問が生じたことは事実である。

以上の既往研究の背景を踏まえ、本論文は Haringx の座屈モデル を見直し、変形の増大を考慮した幾何学的非線形座屈モデルを導き、 座屈安定性に対して重要な要因を解析的に導いた。その上で、既往 研究の結果と若干の比較検討を行った。

\section{2 既往の研究}

せん断変形と曲げ変形を同時に考慮した座屈モデルは、鋼構造の 組み立て圧縮柱の座屈問題として古くから知られている。良く知ら れている組み立て圧縮柱の座屈モデルは中立軸に対して平面が垂直 を維持しながら変形することを仮定している。これを通常 Engesser モデルと呼ぶ。この仮定は、即ち次式の成立を認めたものである。 ここで、sは部材の中立軸に沿った弧長媒介変数とする。

$$
\frac{d M}{d s}=Q(s)
$$

$$
\begin{aligned}
& M(s): \text { 曲げモーメント } \\
& Q(s): \text { せん断力 }
\end{aligned}
$$

通常、幾何学的非線形性や材料非線形を考虑したモデルであって も、式(1)の成立を仮定するのは一般的である。これに対し、Haringx は圧縮コイルバネの座屈安定性が高い理由を理論的に説明するため に、材料の線形性と式(2)を仮定した上で、式(1)が成立しないモデ ルを採用した ${ }^{(5)}$ 。勿論、Engesser モデルは、式(2)の成立も仮定し ている。通常、式(1) と式(2)をセットにして平面保持の仮定と呼ん でいる。Haringx は、式(2)のみが成立するような平面保持の仮定を 設定して、曲げーせん断座屈モデルを作ったのである。

$$
\frac{d \theta(s)}{d s}=-\frac{M(s)}{K_{B}}
$$

$\theta(s)$ :曲げモーメントによるたわみ角

$K_{B}:$ 曲げ岡性 


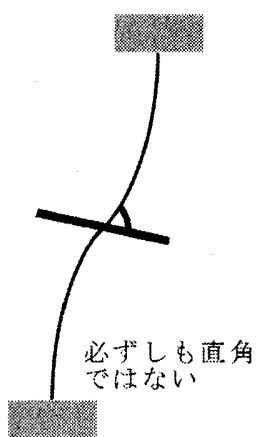

Haringx Model

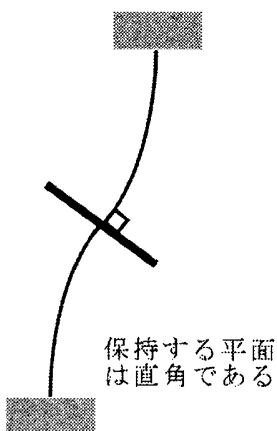

Engesser Model

図 $1 \cdot 2$ 種類の異なる平面保持の仮定

図 1 には Engesser モデルと Haringx モデルの違いを模式的に示し た。積層ゴム支承の座屈実験では、Haringx モデルが実験結果と一致 するとされている(10)。事実、著者が行った中空積層ゴム支承の座屈 実験でも、積層鋼板の曲げ剛性が高い試験体では、Haringx の意味で 平面保持を確保でき、座屈荷重が実験值と良く一致することを確認 している。(本文、第 4 節、写真 1 参照)

しかし、円形断面積層ゴム支承の場合には、比較的小さい水平変 形でも座屈荷重の低下することが知られており、P- $\delta$ 効果による座 屈荷重の補正などが行われている ${ }^{(8)}{ }^{(9)}$ 。一方、著者の行った中空積 層ゴム支承の座屈実験では、断面の直径とほぼ等しい水平変形を加 えても、座屈荷重の低下は見られなかった ${ }^{(4)}$ 。この実験結果は、既 往の実験研究の結果と相反するもので、P- $\delta$ 効果で修正した既往モ デルの妥当性に疑問が生じた。そこで、Haringx モデルについて、今 一度、吟味することから始めることとする。

Haringx は、式(1)を仮定せずに、変形後の釣り合い状態を想定して モデルを構筑した(Appendix 参照)。つまり、 $\mathrm{P}-\delta$ 効果は当初より Haringx モデルに折込済みであることが分かる。従って、既に $\mathrm{P}-\delta$ 効 果を考虑した Haringx そデルに対して、再度 $\mathrm{P}-\delta$ 効果を用いて修正 を施そうとする試みは、論理的な矛盾を内包していることになる。さ らに、今までに提案された $\mathrm{P} 一 \delta$ 効果による修正モデルの多くが、両 端の付加曲げモーメントを積層ゴム支承高さで除してせん断力を求め ているが、この種の計算は、式(1)を暗に仮定したものである。一つの モデルの中に、2 つの両立しない仮定が同居しているようなもので、 このような説明は受け入れ難い。しかしながら、水平変形の増大によ る座屈荷重の低下は多くの実験によって観測されており、Haringx モ デルでは、実験結果を合理的に説明しきれないことも事実なのである。 その理由は、Haringx モデルが微小変形の弾性理論である点にある。 線形理論では、変形の増大に対する座屈荷重の低下を説明できないの は、致し方ないところである。しかし、著者が行った実験では、かな り大きな水平変形を生じた場合にも、線形の Haringx モデルが実験誤 差の範囲で成立している。それでは、どのような条件を满足すると線 形近似が成立するのであろうか。この条件を解明できれば、既往の実 験研究の結果と、著者が行った実験結果の違いを合理的に説明できる はずである。

以上の観点より、本論文では、材料の線形性と式(2)を仮定した上で、 幾何学的非線形モデルを提案し、水平変位の増大が座屈安定性に与え る影響を考察した。以上が、本論文の要旨である。

\section{3 幾何学的非線形を考慮した曲げせん断座届モデル}

幾何学的非線形を考虑した曲げせん断モデルを図 2 に示す。部材中 央部からの部材長 $s$ を媒介変数として、反力と変形の釣り合い式を点 $P(x(s), z(s))$ について求めると式(3)を得る。

$$
\begin{gathered}
M(s)=N_{o} x(s)+Q_{o} z(s) \\
\frac{d x}{d s}=\sin (\theta+\gamma) \\
\frac{d z}{d s}=\cos (\theta+\gamma)
\end{gathered}
$$

ここで、

$s:$ 点 $\mathrm{P}$ を示す弧長媒介変数

$\theta(s)$ : 曲げモーメントによるたわみ角

$\gamma(s)$ : せん断力によるたわみ角

$x(s):$ 点 $\mathrm{P} の x$ 座標

$z(s):$ 点 $\mathrm{P} の z$ 座標

$N(s):$ 点 $\mathrm{P}$ の軸力

$Q(s):$ 点 $\mathrm{P}$ のせん断力

$M(s):$ 点 $\mathrm{P}$ の曲げモーメント

$Q_{o}:$ 部材端せん断力

$N_{o}:$ 部材端軸力

$M_{O}:$ 部材端曲げモーメント

$\delta_{H}:$ 荷重が作用した後の水平変位

$h:$ 荷重が作用した後の部材高さ

$l:$ 荷重が作用した後の部材長さ

ここで、式(3)の両辺を微分すると、次式を得る。

$$
\frac{d M}{d s}=N_{o} \sin (\theta+\gamma)+Q_{o} \cos (\theta+\gamma)
$$

さらに変形すると次式を得る。

$$
\begin{gathered}
\frac{d M}{d s}=\sqrt{N_{o}{ }^{2}+Q_{o}{ }^{2}} \sin \left(\theta+\gamma+\beta_{o}\right) \\
\tan \beta_{o}=\frac{Q_{o}}{N_{o}}
\end{gathered}
$$

せん断力と軸力は次式にて与えられる。

$$
\begin{aligned}
& N(s)=N_{o} \cos \theta-Q_{o} \sin \theta=F_{o} \cos \left(\theta+\beta_{o}\right) \\
& Q(s)=N_{o} \sin \theta+Q_{o} \cos \theta=F_{o} \sin \left(\theta+\beta_{o}\right)
\end{aligned}
$$

式(9)と (10)は座標回転を表しているだけなので次式が成立する。

$$
N^{2}(s)+Q^{2}(s)=N_{o}{ }^{2}+Q_{o}{ }^{2}=F_{o}{ }^{2}
$$

式(7)に加法定理を用い、式(9)、（10）を考虑すると次式を得る。

$$
\frac{d M}{d s}=N(s) \sin \gamma+Q(s) \cos \gamma
$$




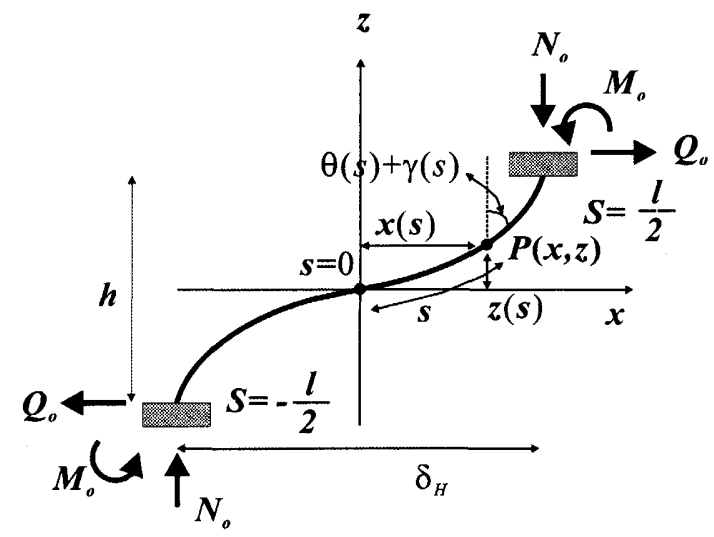

図 2 幾何学的非線形を考慮した曲げせん断モデル

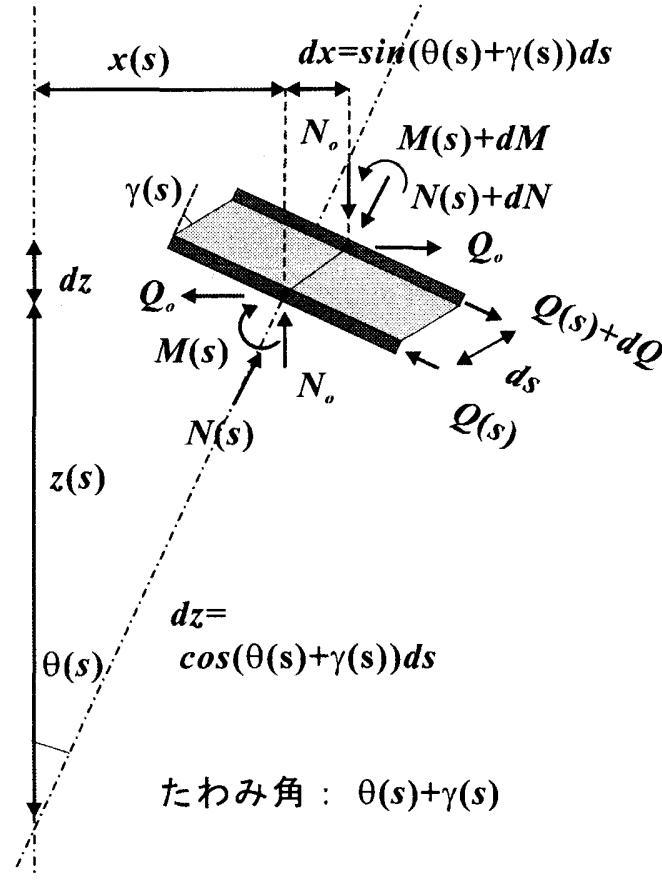

図 3 局部的な釣り合い状態

式(11)を考慮すれば、式(12)は次式となる。

$$
\begin{gathered}
\frac{d M}{d s}=\sqrt{N(s)^{2}+Q(s)^{2}} \sin (\gamma+\beta)=F_{o} \sin (\gamma+\beta) \\
\tan \beta(s)=\frac{Q(s)}{N(s)}
\end{gathered}
$$

式(7) と式(13)から、次式を得る。

$$
\beta(s)=\theta(s)+\beta_{o}
$$

従って、軸力とせん断力は次式によって表される。

$$
\begin{aligned}
& N(s)=F_{o} \cos \beta \\
& Q(s)=F_{o} \sin \beta
\end{aligned}
$$

式(15)を考慮して、曲げ理論式(2)を仮定する。

$$
\frac{d \beta(s)}{d s}=\frac{d \theta(s)}{d s}=-\frac{M(s)}{K_{B}}
$$

さらに、せん断ひずみについては式(17)を参照し、かつ材料の線 形性を仮定すると次式を得る。

$$
\gamma(s)=\frac{Q(s)}{K_{S}}=\frac{F_{o}}{K_{S}} \sin \beta
$$

式(18)の両辺を微分して、式(13)を考虑すると次式を得る。

$$
\frac{d^{2} \beta}{d s^{2}}+\frac{F_{o}}{K_{B}} \sin (\beta+\gamma)=0
$$

式(19)を式(20)に代入すると、最終的に式(21)を得る。

$$
\frac{d^{2} \beta}{d s^{2}}+\frac{F_{o}}{K_{B}} \sin \left(\beta+\frac{F_{o}}{K_{S}} \sin \beta\right)=0
$$

式（21）は幾何学的な非線形性を全て考慮した大変形に対応でき る厳密な非線形方程式である。式(15) を見ると、曲げ変形 $\theta$ が小さ く、かつ軸力が比較的大きい場合、 $\beta$ は部材全域において小さいの で、式(21)は式(22)によって高い精度で近似できる。

$$
\frac{d^{2} \beta}{d s^{2}}+\frac{F_{o}}{K_{B}} \sin \left(\frac{K_{S}+F_{o}}{K_{S}} \beta\right)=0
$$

さらに、式(23)の変数置換を行うと式(22) は式(24)に変形できる。

$$
\varphi(s)=\frac{K_{S}+F_{o}}{K_{S}} \beta(s)=\frac{K_{B}}{F_{o} \lambda_{o}^{2}} \beta(s)
$$

$$
\frac{d^{2} \varphi}{d s^{2}}+\frac{1}{\lambda_{o}{ }^{2}} \sin \varphi=0
$$

$$
\frac{1}{\lambda_{o}^{2}}=\frac{F_{o}^{2}+K_{S} F_{o}}{K_{S} K_{B}}
$$

また、式(13)は式(26)に等しい。

$$
\frac{d M}{d s}=F_{o} \sin \varphi
$$

式 (24) は大振幅を考慮した振り子の非線形振動方程式と等しく、 解は楕円関数 $s n(s, k)$ によって与えられる。従って、变数 $\varphi$ の解は 式(27)で与えられる。ここでcは積分定数である。

$$
\sin \frac{\varphi}{2}=k s n\left(\frac{s}{\lambda_{o}}+c\right)
$$

式(27)の母数 $k$ は、 $\varphi$ の最大值に対して次の関係を満足する。

$$
k=\sin \frac{\varphi_{\max }}{2}
$$


このとき、次式が成立する。

$$
\frac{d \varphi}{d s}=\frac{2 k}{\lambda_{o}} c n\left(\frac{s}{\lambda_{o}}+c\right)
$$

式(18)、（23）を考慮すると次式を得る。

$$
\frac{d \beta}{d s}=\frac{F_{o} \lambda_{o}^{2}}{K_{B}} \frac{d \varphi(s)}{d s}=-\frac{M(s)}{K_{B}}
$$

式(29)と(30)から、曲げモーメントは次式を満足する。

$$
M(s)=-2 k \lambda_{o} F_{o} c n\left(\frac{s}{\lambda_{o}}+c\right)
$$

ここで、境界条件を考慮すると中央部分 $(s=0)$ で曲げモーメ ントはゼロとなる。従って、積分定数 $c$ は第 1 種完全楕円積分 $K(k)$ に等しい。最終的に、曲げモーメント分布の解は次式となる。

$$
M(s)=-2 k \lambda_{o} F_{o} c n\left(\frac{s}{\lambda_{o}}+K(k)\right)
$$

部材端の境界条件は式(33) となる。ここでは、式(15)、(23)を考 慮し、部材長 $l$ が満足すべき $\varphi$ の関数として表現した。

$$
\theta\left(\frac{l}{2}\right)=0 \Leftrightarrow \beta\left(\frac{l}{2}\right)=\beta_{o} \Leftrightarrow \varphi\left(\frac{l}{2}\right)=\frac{Q_{o}}{K_{S}}+\beta_{o}
$$

式(27)を考虑すると、境界条件 (33)は次式で与えられる。

$$
\sin \left(\frac{Q_{o}+\beta_{o} K_{S}}{2 K_{S}}\right)=k s n\left(\frac{l(k)}{2 \lambda_{o}}+K(k)\right)
$$

部材端部で反力が与えられ、変形の大きさは、パラメータ $k$ を選 定すると決まる。このとき、変形後の部材長 $l(k)$ は、式(34)を解く と求めることができる。次に、パラメータ $k$ が与えられたときの水 平変形 $\delta_{H}(k)$ と部材高さ $h(k)$ を求めることにする。まず、変形関 数 $x(s)$ と $z(s)$ は次式で与えられることに注意する。

$$
\begin{aligned}
& x(s)=\int_{0}^{s} \sin (\theta(u)+\gamma(u)) d u=\int_{0}^{s} \sin \left(\varphi(u)-\beta_{o}\right) d u \\
& z(s)=\int_{0}^{s} \cos (\theta(u)+\gamma(u)) d u=\int_{0}^{s} \cos \left(\varphi(u)-\beta_{o}\right) d u
\end{aligned}
$$

従って、下式を得る。

$$
\begin{aligned}
& x(s)=\cos \beta_{o} \int_{0}^{s} \sin \varphi d u-\sin \beta_{o} \int_{0}^{s} \cos \varphi d u \\
& z(s)=\cos \beta_{o} \int_{0}^{s} \cos \varphi d u+\sin \beta_{o} \int_{0}^{s} \sin \varphi d u
\end{aligned}
$$

変形後の部材形状を決定するには、次の積分を評価する必要がある。

$$
\begin{aligned}
& I_{1}=\int_{0}^{l / 2} \sin \varphi d u \\
& I_{2}=\int_{0}^{l / 2} \cos \varphi d u
\end{aligned}
$$

ところで、式(27)からは次の関係式を得る。

$$
\begin{aligned}
& \sin \frac{\varphi}{2}=k s n\left(\frac{u}{\lambda_{o}}+K(k)\right) \\
& \cos \frac{\varphi}{2}=d n\left(\frac{u}{\lambda_{o}}+K(k)\right)
\end{aligned}
$$

式(39)は、式(41)、（42）を用いると式(43)で与えられる。

$$
I_{1}=\int_{0}^{l / 2} 2 \sin \frac{\varphi}{2} \cos \frac{\varphi}{2} d u=-2 k \lambda_{o} c n\left(\frac{l}{2 \lambda_{o}}+K(k)\right)
$$

一方、式(40)は次式に変形できる。

$$
\begin{aligned}
I_{2} & =\int_{0}^{l / 2}\left(2 \cos ^{2} \frac{\varphi}{2}-1\right) d u \\
& =2 \lambda_{o} \int_{K(k)}^{K+l(k) / 2 l_{o}} d n^{2} u d u-\frac{l(k)}{2}
\end{aligned}
$$

ここで、ヤコビのゼータ関数を $z n(s, k)$ とすれば、楕円関数と次 の関倸がある。ここで、 $E(k)$ は第 2 種の完全楕円積分である。

$$
z n(s, k)=\int_{0}^{s} d n^{2} u d u-\frac{E(k)}{K(k)} s
$$

式(45)を式(44)に代入すると、次式を得る。

$$
I_{2}=2 \lambda_{o}\left[z n\left(K(k)+\frac{l(k)}{2 \lambda_{o}}\right)-z n(K)+\frac{E(k)}{K(k)} \frac{l(k)}{2 \lambda_{o}}\right]-\frac{l(k)}{2}
$$

$z n(s, k)$ 関数の加法定理から、式(47)を得る。

$$
\begin{array}{r}
\frac{I_{2}}{2 \lambda_{o}}=z n\left(\frac{l(k)}{2 \lambda_{o}}\right)-k^{2} s n\left(\frac{l(k)}{2 \lambda_{o}}\right) s n\left(K(k)+\frac{l(k)}{2 \lambda_{o}}\right) \\
+\left(\frac{E(k)}{K(k)}-\frac{1}{2}\right)\left(\frac{l(k)}{2 \lambda_{o}}\right)
\end{array}
$$

従って、水平変形と変形後の部材高さを求めると、次式を得る。

$$
\begin{gathered}
\frac{\delta_{H}(k)}{2}=I_{1} \cos \beta_{o}-I_{2} \sin \beta_{o} \\
\frac{h(k)}{2}=I_{2} \cos \beta_{o}+I_{1} \sin \beta_{o}
\end{gathered}
$$

まず、部材断面性能 $K_{B} 、 K_{S}$ を与える。次に部材端部に荷重を 作用させる。荷重に対して $\lambda_{0}$ が、式(25)により定まる。変形の大 きさは楕円関数の母数 $k$ を指定することで決まる。このとき、母数 $k$ に対応した変形後の部材長 $l(k)$ は、式(34) から求まる。高さ $h$ 、 ならびに水平変形量 $\delta_{H}$ は求めた $l(k)$ と与えた $k$ に対して、式 (48) と(49)から与えられる。以上で全ての変数の関係が明らかとなる。 このとき、母数 $k$ に対する座屈荷重の変化する様子を調べれば、水 平変形が座屈荷重に与える影響についても考察することができる。 次節以降は、これらの点について考察する。 


\section{4 座屈荷重近傍における变形の増大と安定性}

\section{(4.1) 部材形状関数}

前節では、任意の荷重を与えた場合の曲げせん断部材の変形を求 めた。本節では部材端軸力 $N_{o}$ が座屈荷重 $N_{c r}$ に近い場合を取り上 げ、水平変位の増大によって座屈荷重がどのように変化するかを考 察する。まず、座屈荷重は部材端部のせん断力 $Q_{o}$ が失われるとき の軸力と定義する。即ち、次式で定義する。

$$
N_{c r}=N_{o} \quad \text { where } Q_{o}=0
$$

まず、座屈荷重を与えたときの基準部材長 $\lambda$ を式(25)に従い、式 （51）で定義する。勿論、座屈荷重もパラメータ $k$ の影響を受ける。

$$
\frac{1}{\lambda^{2}(k)}=\frac{N_{c r}^{2}(k)+K_{S} N_{c r}(k)}{K_{S} K_{B}}
$$

変形後の部材長 $l(k)$ は式(34) から求めることができる。式(8) から $\beta_{o}=0$ となるので、次式が成立する。当然、部材長 $l$ は母数 $k$ の関数となる。

$$
l(k)=2 K(k) \lambda(k)
$$

式(48)からは、式(43)を参照して水平変形が求まる。

$$
\delta_{H}(k)=2 I_{1}(k)=4 k \lambda(k)
$$

さらに、 $z n(K(k))=0$ を考虑すると、式(49)は式(54)に等しい。

$$
h(k)=2(2 E(k)-K(k)) \lambda(k)
$$

軸剛性を無限大と仮定すると積層ゴム一層ごとの厚みは変化しな い。従って、部材の元の長さ $l_{o}$ は図 3 を参照して次式で与えられる。

$$
l_{o}=2 \int_{0}^{1 / 2} \cos \gamma d s=2 \int_{0}^{1 / 2} \cos (\varphi-\beta) d s
$$

$\beta$ が微小であることを考慮すると次式で近似できる。

$$
l_{o}=2 \int_{0}^{l / 2} \cos \varphi d s+2 \int_{0}^{l / 2} \beta \sin \varphi d s
$$

第 2 項を変形すると式(26)を参照して、次式を得る。

$$
\int_{0}^{l / 2} \beta \sin \varphi d s=\int_{0}^{l / 2} \frac{\beta}{F_{o}}\left(\frac{d M}{d s}\right) d s
$$

座屈状態であることを考慮し、部分積分をすると式(58)を得る。

$$
\begin{gathered}
\int_{0}^{1 / 2} \frac{\beta}{N_{c r}}\left(\frac{d M}{d s}\right) d s=\left|\frac{\beta(s) M(s)}{N_{c r}}\right|_{o}^{1 / 2}-\int_{0}^{l / 2} \frac{M(s)}{N_{c r}}\left(\frac{d \beta}{d s}\right) d s \\
=\frac{1}{N_{c r} K_{B}} \int_{0}^{l / 2} M^{2}(s) d s \\
=\frac{4 k^{2} \lambda^{2} N_{c r}}{K_{B}} \int_{0}^{1 / 2} c n^{2}\left(\frac{s}{\lambda(k)}+K(k)\right) d s
\end{gathered}
$$

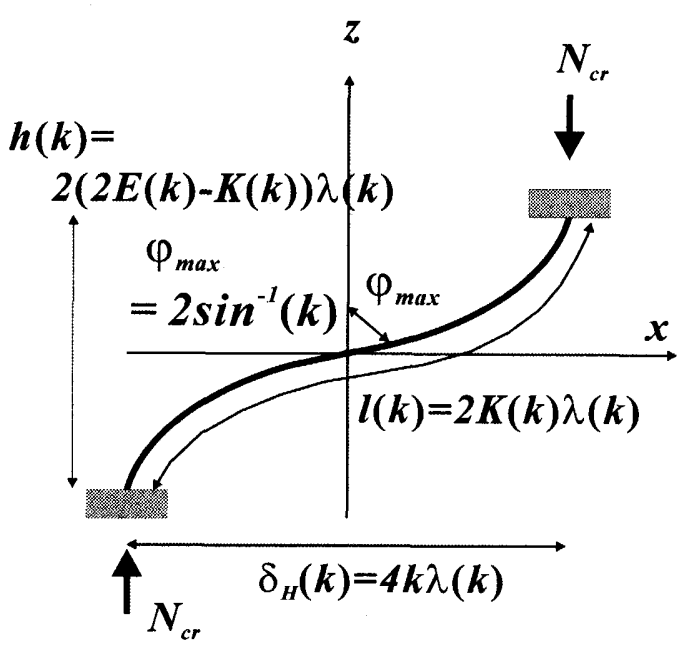

図 4 座屈荷重近傍における部材変形を表す関数グループ

ここで、式(59)に注意すれば、式(57)は式(60)に等しい。

$$
\int_{0}^{l / 2} c n^{2}\left(\frac{s}{\lambda(k)}+K(k)\right) d s=\frac{k^{2}-1}{k^{2}}\left(\frac{l(k)}{2}\right)+\frac{\lambda(k)}{k^{2}} E(k)
$$

$$
\int_{0}^{l / 2} \beta \sin \varphi d s=\frac{4 \lambda^{2} N_{c r}}{K_{B}}\left(\lambda(k) E(k)+\frac{l(k)}{2}\left(k^{2}-1\right)\right)
$$

従って、式(56)は式(61)に等しい。

$$
\begin{aligned}
l_{o}=2( & \left.\frac{E(k)}{K(k)}-\frac{1}{2}\right) l(k) \\
& +\frac{4 \lambda^{2} N_{c r}}{K_{B}}\left(2 \lambda E(k)+k^{2} l(k)-l(k)\right)
\end{aligned}
$$

式(52)を考慮すると、次式を得る。

$$
\begin{aligned}
& l_{o}=2(2 E(k)-K(k)) \lambda(k) \\
& \quad+\frac{8 \lambda^{3}(k) N_{c r}(k)}{K_{B}}\left(E(k)+\left(k^{2}-1\right) K(k)\right)
\end{aligned}
$$

以上で、大変形後の部材形状を表現できる関数グループが求まっ た。変形後の部材長が式(52) によって、水平変位が式 (53)によって、 それぞれ求められる。さらに、ゴム支承の高さは式(54)で評価でき る。これらの関係を図 4 に示す。

曲げ剛性のみを考慮した大変形モデルはよく知られており、通常 部材長 $l$ を定数と見なしている。ところが、積層ゴム支承では荷重 載荷後に部材長が大きく伸びるため、従来の大変形モデルでは非線 形解析が不可能であった。この小論で示したモデルは、大変形後に 部材長が伸びる場合にも、幾何学的な非線形性を考虑できる。

式(51) と (62) は、水平変位が増大した後に座屈荷重 $N_{c r}$ と基準部 材長 $\lambda(k)$ が満足す心゙き関係を示している。結局、この 5 つの関係式 にパラメータ $k$ を代入すると、具体的な変形を決定することができ る。ただし、座屈荷重 $N_{c r}(k)$ 注、係数が完全楕円積分を含む $k$ の関 数となる 4 次方程式の解、として与えられるので複雑である。 


\section{（4. 2）微小变形の場合 : $k=0$}

最初に、水平変位が極めて小さい場合の座屈荷重について考察す る。このとき、座屈荷重は Haringx の微小変形理論解と一致しなけ ればならないはずである。ここでは、母数 $k=0$ の場合が対応する。 式(52) と (54) を参照すると次の関係が得られる。部材長も支承高さ も、荷重を載荷する前の部材長さ $l_{o}$ に等しい。

$$
l(0)=h(0)=l_{o}
$$

このときの座屈荷重は特別なので、次式で定義する。この結果は、 Haringx モデルの微小変形理論による座屈荷重と一致することが確 かめられた。(Appendix 参照)

$$
\begin{aligned}
\frac{N_{H}^{2}+K_{S} N_{H}}{K_{S} K_{B}} & =\left(\frac{1}{\lambda_{H}}\right)^{2}=\left(\frac{\pi}{l_{o}}\right)^{2} . \\
N_{c r}(0) & =N_{H}
\end{aligned}
$$

\section{（4.3）若干変形が進んだ状態: $0<k<0.3$}

水平変位が増大すると、座屈荷重は低下するのであろうか、それ とも増大するのであろうか。既往研究の結果は、前者の結果を支持 している。しかし、著者の実験結果では座屈荷重の変動は少なかっ た。この実験結果の違いを考察する。

そのためには、パラメータ $k$ と座屈荷重 $N_{c r}(k)$ の関係を求めな ければならない。満足す心゙き方程式は、式(51) と（62)である。基準 部材長 $\lambda$ を消去すると、座屈荷重 $N_{c r}$ についての 4 次方程式が得ら れる。4 次方程式の各係数は $k$ についての関数であるから、 $N_{c r}$ の 解は $k$ についての関数となる。

しかし、この問題を直接解くのは困難である。そこで、 $k$ の動く 範囲を比較的微小な篹囲に限定し、楕円積分を級数展開によって近 似する。第 1 種完全楕円積分と第 2 種完全楕円積分で、4 次式以上 の項を無視すれば、それぞれ次式で近似できる。

$$
\begin{aligned}
& K(k)=\frac{\pi}{2}\left(1+\frac{k^{2}}{4}+\frac{9}{64} k^{4} \ldots\right) \fallingdotseq \frac{\pi}{2}\left(1+\frac{k^{2}}{4}\right) \\
& E(k)=\frac{\pi}{2}\left(1-\frac{k^{2}}{4}-\frac{3}{64} k^{4} \ldots\right) \doteqdot \frac{\pi}{2}\left(1-\frac{k^{2}}{4}\right)
\end{aligned}
$$

式 (66)、(67) を式(62)に代入すると次式を得る。ここでは再び $k^{4}$ 以上の項を無視した。従って、 $k^{4}$ の項が $k^{2}$ の項に比較して無視で きる(桁が異なる) 範囲を若干変形が進んだ状態と定義し、 $k$ が 0.3 以下の範囲で考えることとした。

$$
l_{o}=\pi\left(1-\frac{3}{4} k^{2}\right) \lambda(k)+\frac{2 \pi \lambda^{3}(k) N_{c r}(k)}{K_{B}} k^{2}
$$

$k$ について解くと、次式を得る。

$$
k^{2}=\frac{4 K_{B}\left(l_{o}-\pi \lambda(k)\right)}{\pi \lambda(k)\left(8 \lambda^{2}(k) N_{c r}(k)-3 K_{B}\right)}
$$

水平変位を増大させたので、パラメータ $k$ は必ず正の解を持つ。

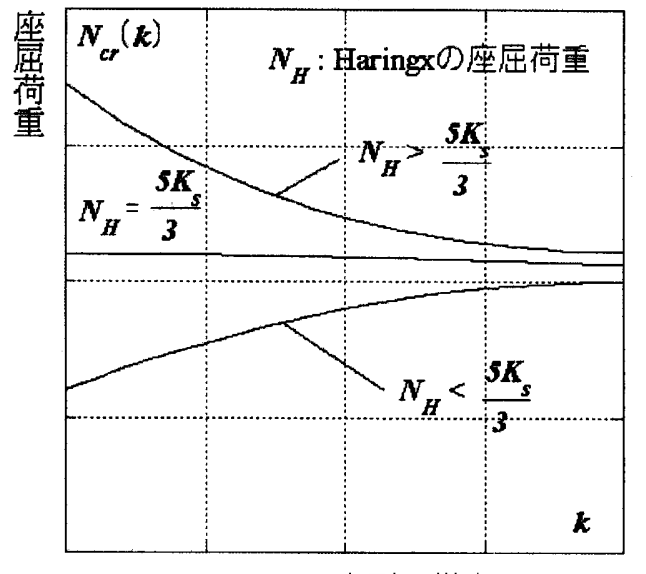

変形の增大 $\rightarrow$

図 5 変形 $k$ の増大と座屈荷重 $N_{c r}$ の変化

逆に考えると、次の場合分けが必ず成立する。

$$
\left\{\begin{array}{lll}
8 \lambda^{2} N_{c r}-3 K_{B}>0 & \Leftrightarrow & l_{o}-\pi \lambda>0 \\
8 \lambda^{2} N_{c r}-3 K_{B}<0 & \Leftrightarrow & l_{o}-\pi \lambda<0
\end{array}\right.
$$

ここで、式(51)を考虑すると式(70)は(71)式と等しい。

$$
\begin{cases}N_{H}<\frac{5 K_{S}}{3} & \Leftrightarrow \lambda(k)<\frac{l_{o}}{\pi}=\lambda_{H} \\ N_{H}>\frac{5 K_{S}}{3} & \Leftrightarrow \quad \lambda(k)>\frac{l_{o}}{\pi}=\lambda_{H}\end{cases}
$$

従って、部材のせん断剛性 $K_{S}$ がある程度高い場合、水平変位の 增大に対して、基淮部材長 $\lambda(k)$ は短くなる。つまり、座屈荷重は減 少するのではなく、若干增加に転じる。逆にせん断剛性が低すぎる と、水平変位の増大に対して座屈荷重は直ちに減少し始める。

式(71)の結果を、図 5 に模式的に示した。式(71) と図 5 を参照す れば、水平変位の増大に対して基準部材長 $\lambda か ゙$ 増大しない、言い換 えると、座屈荷重が安定に推移するための判定条件を求めることが できる。

$$
N_{H}<\frac{5 K_{S}}{3}
$$

式 (72) は極めて意外な結果と言わざるを得ない。従来の免震用積 層ゴム支承の開発方針は、より低いせん断剛性を持ち、より高い軸 力を支持できる部材を追求する方向にあった。しかし、式(72)は高 い軸力を支持し、低いせん断剛性を持つ部材は、水平変位の増大に 対して座屈安定性が劣化することを示している。従って、材料のせ ん断弾性係数は、ある程度の絶対值が必要であり、際限なく低いせ ん断弾性係数の材料を開発したり、追求したりすることは、座屈安 定性の観点からは控えるべきであることが理解できるのである。

以上のように、広く用いられている積層ゴム支承の座屈安定性に ついて、従来の見解とは質的に異なる結果が導かれた。今後は、式 (72)の妥当性を実験で再現することが必要である。この解析予想を 検証することは、現在、危惧されている長周期地震に対する免震構 造の安全性を検討するためにも、重要な課題である。 


\section{(4. 4) 大変形領域 : $0.5<k<0.8$}

最後に終局的な場合を想定し、水平変位が非常に大きくなった場 合について考察する。寒は、水平変位がどれほど大きくなっても、 部材長 $l(k)$ に対する水平変形 $\delta_{H}(k)$ の割合には最大值が存在する。 式 (52) と式 (53) を参照して、水平変位と変形後の部材長の比率を母 数 $k$ の関数で表すと、式(73)を得る。図 6 にはグラフを示した。

$$
\frac{\delta_{H}}{l}=\frac{2 k}{K(k)}
$$

図 6 からは、母数 $k$ が 0.80 よりも大きくなると部材長が水平変形 に対して極端に大きくなることが分かる。このような変形状態を模 式的に図示すると図 7 となる。従って、 $k$ が 0.8 を超えるような変 形は、避けなければならないことは、直ちに理解できる。

では、座屈荷重の低下を招かないためには、 $k$ は如何なる範囲に 留めるべきなのであろうか。図7から分かるように $\varphi_{\max }$ が $\pi / 2$ を 超えるような大変形は危険である。対応する $k$ の限界值は $\sqrt{2} / 2$ で あり、これを一つの目安とすることにした。このときの、水平変形 の值を安定限界水平変位 $\delta_{c r}$ と定義することにする。積層ゴム支承 の全高さ $h(k)$ は、水平変位の増大とともに減少する。従って、水平 変位と全高さの比率を考えることで、安定限界水平変位 $\delta_{c r}$ の上界 を定めることができる。式(53)、(54)より $\delta_{c r}$ の上限は次式で与え られる。

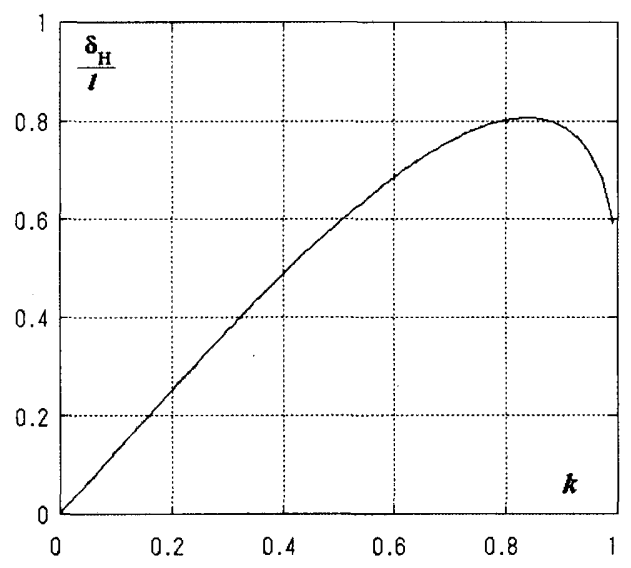

図 6 母数の変化に対する部材長と水平変位の比率

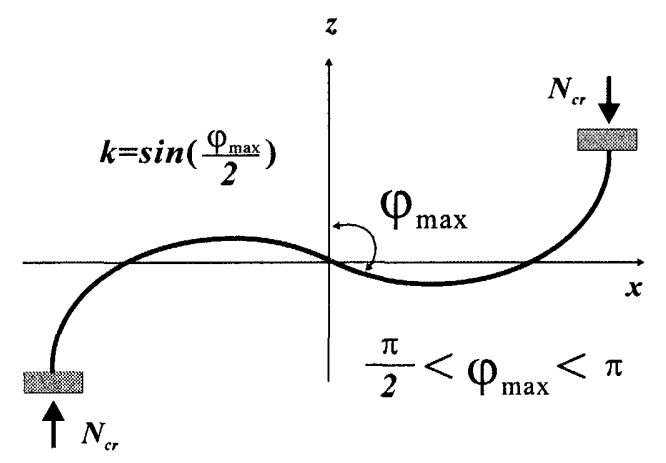

図 7 安定限界変位を超えた変形とパラメータ $k$ の関係

$$
\delta_{c r}=\frac{2 k h(k)}{2 E(k)-K(k)}<\frac{\sqrt{2} l_{o}}{2 E\left(\frac{\sqrt{2}}{2}\right)-K\left(\frac{\sqrt{2}}{2}\right)}=1.60 l_{o}
$$

水平変位が式(74)を超えて変形するときは、材料剛性が硬化しな い限り、座屈荷重の低下を避けることができない。一般的に用いら れている免震構造用積層ゴム支承では、この点が全く考慮されてい ない。寧ろ、積層ゴム支承の全高さは、2 次形状係数がある数值目標 を満足する範囲で低めに抑えられてきた。既往研究では積層ゴム支 承の直径のみに着目していたため、積層ゴム支承の絶対的な高さが、 座屈安定性を確保するために必要な最小値に比べて少なすぎるよう に思われる。ただ、せん断剛性はひずみの増大により硬化するので、 変形の增大に対する幾何学的な不安定性を、幾分補う効果があるも のと推定できるので、今後は材料非線形が座屈安定性に与える効果 を含めて総合的に評価することが必要である。

\section{（4.5）実験結果との比較}

著者は中空積層ゴム支承を対象として、幾つかの実験研究を行っ てきた。写真 1 には、水平変位 $200 \mathrm{~mm}$ 、鉛直軸力 $263 \mathrm{KN}$ 、水平反力 ゼロ、の場合の中空積層ゴムの変形状態を示す。試験体の諸元、実 験方法、計測方法、材料定数の計測方法など、定量的な実験結果に ついては文献 4 を参照されたい。ここでは、定性的な実験結果を、 解析結果から考察することとする。

積層鋼板の厚みが十分にある場合は、Haringx の意味で平面保持が 成立する (写真参照)。また、座屈荷重は実験誤差の範囲で Haringx の線形理論で予測できる( ${ }^{(4)}$ 。水平変位が直径とほぼ等しい場合にも、 座屈荷重の低下が殆ど見られないことが、実験によって確認された。 こうした座屈後の安定性は、少なくとも解析的には存在することが 示されたし、実験的にも現象を捉えることができた。おそらく、中 空積層ゴムに限らず円形断面の積層ゴム支承でも条件さえ調えば同 様の現象を観測できるはずである。

本論文で解析的に示した結果は、既往の研究成果とは質的に異な る。既往の実験研究では試されていない断面形状やプロポーション、 高めのせん断弹性係数の設定など、様々な要因が座屈安定性を向上 させる可能性として残されていることを、本論文の解析予想は示し ているのである。

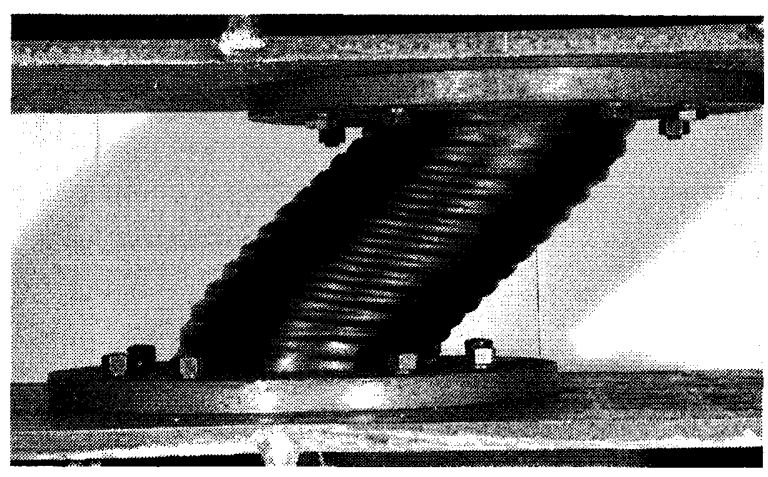

水平変位 $200 \mathrm{~mm}$ 鉛直軸力 $263 \mathrm{KN}$ 写真 1 中空積層ゴムの座屈後変形 


\section{5 結 語}

本論文では、材料の線形性と積層鋼板の平面保持を前提とし、幾 何学的な非線形性が積層ゴム支承の座屈安定性に与える影響につい て、解析的な考察を行った。その結果、幾つかの新しい知見と解析 予想を得るに至った。

1. 線形の曲げーせん断座屈モデル（Haringx モデル）を大変形 領域に拡張した非線形座屈モデルを導いた。

2. 大きな水平変形状態における、座屈後の部材変形を棈円積分 のグループによって表現することが可能となった。

3. 上記、拡張モデルを用いると、部材のせん断弾性係数の絶対 值が座屈後の安定性を支配する重要な因子となっている可 能性が予想される。

4.さらに、積層ゴム支承の高さ方向の絶対值が座屈後の安定性 に大きな影響を与えている可能性が予想される。

上記の結果は、普通に使用されている免震構造用積層ゴム支承の 多くが、水平変形に対する座屈安定性という基本的な条件を必ずし も十分に満足しているとは言い切れないことを示している。

一方、既往の実験研究では試されていない断面形状やプロポーシ ヨン、材料定数の設定など、様々な要因が座屈後の安定性を向上さ せる可能性として残っていることも解析的には予想されるのである。

\section{謝辞}

本研究の一部は、日本学術振興会科学研究費補助金・基盤研究 (C)（2）（課題番号 14550583、木造家屋のための免震構造用積層ゴム 支承の開発）より助成を受けたものでありここに記して謝意を表す。

\section{参考文献}

1）西村功、山田俊一、坂本光雄、近藤明洋、小堀鐸二:中空断面を有寸る皘 層ゴム支承の鉛直剛性に関する解析的研究、日本建築学会構造系論文集、第 505 号、pp. 61-68、1998 年 3 月

2）西村功、山田俊一、坂本光雄、近藤明洋、小堀鐸二：中空断面を有寸る糟 層ゴム支承の鉛直剛性に関する実験的研究、日本建築学会構造系論文集、第 519 号、pp. 143-150、1999 年 5 月

3）西村功：中空断面を有する積層ゴム支承の曲げ岡性に関する解析的研究、 日本建築学会構造系論文集、第 558 号、pp. 149-156、2002 年 8 月

4）西村功、小木亜希子、今泉幸成：中空断面を有する積層ゴム支承の座屈荷 重に関する実験、日本建築学会構造系論文集、第 586 号、PP. 79-86、2004 年 12 月

5) Haringx, J. A. : On Highly Compressible Helical Springs and Rubber Rods, and Their Application for Vibration-Free Mountings I, Phillips Research Report, Vol. 3, pp. 401-449, 1948

6) Haringx, J. A. : On Highly Compressible Helical Springs and Rubber Rods, and Their Application for Vibration-Free Mountings II, Phillips Research Report, Vol.4, pp. 49-80, 1949

7) Haringx, J. A. : On Highly Compressible Helical Springs and Rubber Rods, and Their Application for Vibration-Free Mountings III, Phillips Research Report, Vol. 3, pp. 206-220, 1949

8) Buckle, I. G., Kelly, J. M. : Properties of Slender Elastomeric Isolation Bearings during Shake Table Studies of a Large-Scale Model Bridge Deck, Joint Sealing and Bearing Systems for Concrete Structures, ACI, vol. 1, pp. 247-269, 1986

9) Buckle, I. G., Liu, H. : Stability of elastomeric seismic isolation systems, Proc. of Seminar on Seismic Isolation, Passive Energy Dissipation and Control, ATC-17-1, Applied Technology Council, pp. 293-305, 1993

10) Gent,A.N. : Elastic Stability of Rubber Compression Springs, Journal Mechanical Engineering Science, Vol.6, No.4, pp. 318-326, 1964

\section{[APPENDIX] Haringx Model}

部材端部の境界条件は下式にて与えられる。（本文図 2 参照）

$$
M_{o}=\frac{1}{2} N_{o} \delta_{H}+\frac{1}{2} h Q_{o}
$$

部材中間点における曲げモーメントの釣り合いは、図 3 を参照し て、式 (A-2) となる。

$$
\begin{gathered}
M(z)=N_{o} x(z)+Q_{o} z \\
\frac{d M}{d z}=N_{o} \frac{d x}{d z}+Q_{o} \\
\frac{d x}{d z}=\theta(z)+\gamma(z) \\
Q(z)=Q_{o}+N_{o} \theta(z) \\
\gamma(z)=\frac{Q(z)}{K_{S}} \\
\frac{d \theta}{d z}=-\frac{M_{(z)}}{K_{B}}
\end{gathered}
$$

以上が、Haringx の曲げーせん断モデルである。境界条件を考虑し て、水平変位の解は $(\mathrm{A}-8)$ となる。

$$
x(z)=\frac{M_{o}}{N_{o}} \frac{\sin \left(\omega_{o} z\right)}{\sin \left(\frac{\omega_{o} h}{2}\right)}-\frac{Q_{o}}{N_{o}} z
$$

ここで、

$$
\omega_{o}^{2}=\frac{N_{o}}{K_{B}}\left(1+\frac{N_{o}}{K_{S}}\right)
$$

水平剛性を式 $(A-10)$ で定義すると、その值は式(A-11) で与えられる。

$$
\begin{gathered}
Q_{o}=K_{E} \delta_{H} \\
K_{E}=\frac{N_{o}^{2}}{2 \omega_{o} K_{B} \tan \left(\frac{\omega_{o} h}{2}\right)-h N_{o}}
\end{gathered}
$$

最後に座屈荷重を算定する。水平剛性が消失する鉛直軸力を座屈荷 重と定義すると、その值は次式で与えられる。

$$
\cos \left(\frac{\omega_{o} h}{2}\right)=0
$$

結局、座屈荷重 $N_{H}$ は、2 次方程式の根のうち、プラス側の解で与え られる。この解は、本文の式（64）に等しい。

$$
N_{H}^{2}+K_{S} N_{H}-K_{B} K_{S}\left(\frac{\pi}{h}\right)^{2}=0
$$

(2004年10月 26 日原稿受理, 2005 年 3 月 22 日採用決定) 